\title{
Detection and Control of Fusarium oxysporum from Soft Rot in Dendrobium officinale by Loop-Mediated Isothermal Amplification Assays
}

\author{
Caiyun Xiao ${ }^{1,2,3}$ and Rongyu Li ${ }^{1,2,3, *}$ \\ 1 Institute of Crop Protection, Guizhou University, Guiyang 550025, China; xcy971006@126.com \\ 2 The Provincial Key Laboratory for Agricultural Pest Management in Mountainous Region, \\ Guiyang 550025, China \\ 3 College of Agriculture, Guizhou University, Guiyang 550025, China \\ * Correspondence: ryli@gzu.edu.cn or lirongyu0328@126.com
}

check for updates

Citation: Xiao, C.; Li, R. Detection and Control of Fusarium oxysporum from Soft Rot in Dendrobium officinale by Loop-Mediated Isothermal Amplification Assays. Biology 2021, 10, 1136. https://doi.org/10.3390/ biology10111136

Academic Editor: Luigi De Bellis

Received: 8 October 2021

Accepted: 3 November 2021

Published: 5 November 2021

Publisher's Note: MDPI stays neutral with regard to jurisdictional claims in published maps and institutional affiliations.

Copyright: (c) 2021 by the authors. Licensee MDPI, Basel, Switzerland. This article is an open access article distributed under the terms and conditions of the Creative Commons Attribution (CC BY) license (https:// creativecommons.org/licenses/by/ $4.0 /)$.
Simple Summary: In this study, we investigated the soft rot disease of Dendrobium officinale in Guizhou Province, and designed a rapid method to detect the pathogen is Fusarium oxysporum in Dendrobium officinale by using specific gene sequences and loop-mediated isothermal amplification technology. This method can accurately detect Fusarium oxysporum on soft rot plants of Dendrobium officinale. Therefore, the results of this study are crucial for the early diagnosis of soft rot on Dendrobium officinale.

Abstract: Soft rot causing Fusarium oxysporum is one of the most destructive diseases of Dendrobium officinale Kimura et Migo in China that reduces D. officinale yield and quality. A key challenge for an integrated management strategy for this disease is the rapid and accurate detection of $F$. oxysporum on D. officinale. Therefore, a new loop-mediated isothermal amplification (LAMP) assay was developed for this purpose. In this study, the primers were selected and designed using the translation elongation factor- $1 \alpha(T E F-1 \alpha)$ gene region as the target DNA sequence in order to screen the best system of reaction of LAMP to detect F. oxysporum through optimizing different conditions of the LAMP reaction, including time, temperature, concentrations of $\mathrm{MgSO}_{4}$, and concentrations of inner and outer primers. The optimized system was able to efficiently amplify the target gene at $62{ }^{\circ} \mathrm{C}$ for 60 min with $1.2 \mu \mathrm{M}$ internal primers, $0.4 \mu \mathrm{M}$ external primers, $7 \mathrm{mM} \mathrm{Mg}^{2+}$, and $5 \mathrm{fg} / \mu \mathrm{L}$ minimum detection concentration of DNA for F. oxysporum. The amplified products could be detected with the naked eye after completion of the reaction with SYBR green I. We were better able to control the effect of soft rot in D. officinale using fungicides following a positive test result. Additionally, the control effect of synergism combinations against soft rot was higher than $75 \%$. Thus, LAMP assays could detect F. oxysporum in infected tissues of D. officinale and soils in field, allowing for early diagnosis of the disease.

Keywords: Fusarium oxysporum; soft rot on Dendrobium officinale; loop-mediated isothermal amplification; translation elongation factor- $1 \alpha$

\section{Introduction}

Dendrobium officinale Kimura et Migo is a perennial herb belonging to the Orchidaceae Dendrobium Sw. that is commonly used in traditional Chinese medicine [1,2]. Most studies have shown that $D$. officinale contains abundant mineral elements, amino acids, and fatty acids, which explains its high medicinal value $[3,4]$. Modern pharmacological studies have proven that its components have a variety of effects, including antitumor, enhanced immunity, and reduced blood sugar, among others [5,6]. D. officinale is distributed in east Asia, southeast Asia, and Australia, along with a few other countries or regions. It is mainly distributed in the southern subtropical areas of China $[7,8]$. However, D. officinale requires a 
very specific growth environment and particular climactic conditions. It also grows slowly so the wild resources are very scarce $[9,10]$. With increasing market demand for $D$. officinale, people often choose to imitate the wild cultivation of $D$. officinale [11,12].

The imitated wild cultivation of D. officinale is often planted under forests and on the shady sides of stones $[13,14]$. High humidity, poor ventilation, and relative sultriness are conducive to the occurrence of diseases. Nowadays, soft rot caused by F. oxysporum is one of the most harmful diseases in D. officinale production, which can occur throughout the year. In particular, soft rot is one of the diseases that frequently occurs in D. officinale in Guizhou province, which is mostly caused by Fusarium oxysporum. The incidence of soft rot is from 30 to $50 \%$ after surveying seven regions of D. officinale in Guizhou, according to many surveys in our lab. The mode of transmission of $F$. oxysporum is horizontal transmission, which can infect the root or root neck of the plant. The mycelium living in the soil permeates the root through the seed and then infects the stem $[15,16]$. The pathogens invade the tissue through the large space between the outer skin cells of the plant. The mycelium and spores enter vessels and vascular tissues and expand into all parts of the plant $[17,18]$. When the temperature and humidity are ideal, F. oxysporum is infected rapidly. Roots, stems, and leaves begin to show symptoms of disease three days after infection $[19,20]$. Besides the damage inflicted on tubers, F. oxysporum also produces mycotoxins, which are harmful to humans and animals [21-23]. Therefore, it is necessary to develop a rapid method for the early diagnosis of soft rot in $D$. officinale for disease control.

Currently, the traditional pathogen isolation process includes separation, purification, microscope observation, and physiological biochemical determination. Conventional PCR identification requires special equipment and experienced technicians and takes several hours to conduct. Thus, it is not suitable for application beyond the specialist level [24,25]. A more specialized detection method, loop-mediated isothermal amplification (LAMP), is a new detection method that can efficiently amplify nucleic acid. It is widely used in the rapid detection of pathogens [26-28]. LAMP assays consist of two pairs of primers for six regionally identified target sequences, and substitute DNA polymerase chains under constant temperature without thermal cycler for active Bst [29-31]. The LAMP product can be used for real-time monitoring, adding SYBR Green I, hydroxynaphthol blue (HNB), calcein, or gel electrophoresis [32,33]. Therefore, there is no need for expensive specialist equipment, such as thermal circulators, and LAMP assays are suitable for the detection and identification of pathogens [34]. F. oxysporum is one of the pathogens that causes soft rot in D. officinale, but Fusarium. sp. are a complex group, which is reflected in their rich genetic diversity, high genome variability, and wide range of hosts [35,36]. Therefore, we need accurate and specific molecular markers of soft $\operatorname{rot}(F$. oxysporum) in D. officinale. This study is based on using the TEF-1 $\alpha$ gene of $F$. oxysporum to design a new set of LAMPspecific primers, following which the conditions of the LAMP assays were explored and optimized. We use mycelium and DNA extracted from fungi on pathogenic plant tissues to test the specificity, sensitivity, and stability of this method. This work provides an early and rapid diagnostic method for soft rot (F. oxysporum) in D. officinale for proper and timely disease control.

\section{Materials and Methods}

\subsection{Strains}

Fusarium oxysporum strains were isolated from samples of soft rot in D. officinale collected from different areas of Guizhou province, China. F. oxysporum strains were identified by their morphological characteristics, sequence analyses of the rDNA internal transcribed spacer (ITS), and translation elongation factor 1-alpha (TEF-1 $\alpha$ ) genes using primers ITS4/ITS5 [37] and EF1/EF2 [38]. All strains were preserved at Guizhou University (Table 1). 
Table 1. Different strains of fungus used in this study to test the specificity of the LAMP assay.

\begin{tabular}{|c|c|c|c|c|c|}
\hline \multirow{2}{*}{ Species } & \multirow{2}{*}{ Host } & \multirow{2}{*}{$\begin{array}{l}\text { Geographical } \\
\text { Location }\end{array}$} & \multirow{2}{*}{ Number of Strains } & \multicolumn{2}{|c|}{ LAMP detection } \\
\hline & & & & Agarose Gel & SYBR Green I \\
\hline Fusarium oxysporum & Dendrobium officinale & Xingyi, Guizhou & 1 & + & + \\
\hline Fusarium proliferatum & Dendrobium officinale & Huaxi, Guiyang & 1 & - & - \\
\hline Fusarium equiseti & Dendrobium officinale & Huaxi, Guiyang & 1 & - & - \\
\hline Fusarium solani & Dendrobium officinale & Libo, Guiyang & 1 & - & - \\
\hline Fusarium chlamydosporum & Dendrobium officinale & Anlong, Guiyang & 1 & - & - \\
\hline Fusarium fujikuroi & Plum & Huishui, Guiyang & 1 & - & - \\
\hline Fusarium graminearum & Kiwi Fruit & Xifeng, Guiyang & 1 & - & - \\
\hline Colletotrichum fructicola & Dendrobium officinale & Sansui, Guizhou & 1 & - & - \\
\hline Epicoccum sorghinum & Dendrobium officinale & Xingyi, Guizhou & 1 & - & - \\
\hline Neurospora sitophila & Dendrobium officinale & Jinping, Guizhou & 1 & - & - \\
\hline Lasiodiplodia pseudotheobromae & Dendrobium officinale & Jinping, Guizhou & 1 & - & - \\
\hline Trichoderma harzianum & Soil & Jinping, Guizhou & 1 & - & - \\
\hline Botryosphaeria dothidea & Dendrobium officinale & Jinping, Guizhou & 1 & - & - \\
\hline Phomopsis sp. & Kiwi Fruit & Xifeng, Guizhou & 1 & - & - \\
\hline Pythium ultimum & Dendrobium officinale & Huaxi, Guizhou & 1 & - & - \\
\hline Magnaporthe grisea & Oryza sativa & Huaxi, Guizhou & 1 & - & - \\
\hline Rhizoctonia solani & Oryza sativa & Huaxi, Guizhou & 1 & - & - \\
\hline Botrytis cinerea & Kiwi Fruit & Xifeng, Guizhou & 1 & - & - \\
\hline
\end{tabular}

Note: bold letter $=$ the Fusarium oxysporum used for specific detection in this study.

\subsection{Isolation and Purification of Strain}

The pathogens were isolated by a conventional tissue isolation method. Symptomatic tips of $D$. officinale stems and rots were collected from Guizhou province in China during 2019-2020. Samples of approximately 3-4 $\times 2-3 \mathrm{~mm}$ were taken from the margin of necrosis at the stem base of $D$. officinale, disinfected in $75 \%$ ethyl alcohol for $5 \mathrm{~s}$, and then rinsed three times in sterile distilled water. Small pieces of tissue were soaked up in sterilized water with filter paper and plated on potato dextrose agar (PDA) culture at $25{ }^{\circ} \mathrm{C}$ for $7 \mathrm{~d}$. The morphological characteristics of isolates, including colony texture and color, size, and conidiophores, were assessed. The purified strains were transferred to slope PDA for preservation.

\subsection{DNA Extraction}

Mycelia of F. oxysporum were grown at $25^{\circ} \mathrm{C}$ for $3-5 \mathrm{~d}$ for DNA extraction. Genomic DNA was extracted from mycelia using a fungal gDNA isolation kit (Hangzhou Biomedical Technology Co., Ltd., Hangzhou, Zhejianng, China). The concentration of DNA was determined by spectrophotometry at $260 \mathrm{~nm}$ and the purity of the nucleic acid was evaluated by the ratio of absorbance at 260 to $280 \mathrm{~nm}$. Genomic DNA was diluted to a concentration of $50 \mathrm{ng} / \mu \mathrm{L}$ and then stored at $-20{ }^{\circ} \mathrm{C}$ until use.

\subsection{Primers Design}

We used a molecular evolutionary genetics analysis (MEGA7.0) program to perform a phylogenetic analysis based on the TEF-1 $\alpha$ gene sequence. The basic local alignment search tool (BLAST-N) software (http:/ /blast.ncbi.nlm.nih.gov, 7 October 2021) was used to compare the sequences with other sequences of the genus Fusarium from the national biotechnology information center (NCBI). The alignment analysis was carried out using MEGA7.0 software. The phylogenetic tree was constructed using a data analysis model and the adjacency method (neighbor-joining). The bootstrap support value (bootstrap) was 1000. In the phylogenetic tree, the strain XY1E208 was in the same branch as F. oxysporum, being isolated from other Fusarium species (Figure 1). Therefore, the gene sequence of $T E F-1 \alpha$ could be used to distinguish different species of F. oxysporum. We determined the base sequence of TEF-1a using a conserved region of F. oxysporum and used ClustalX software to compare and analyze the base sequence of the TEF-1 $\alpha$ gene between different species of Fusarium and other pathogens. 


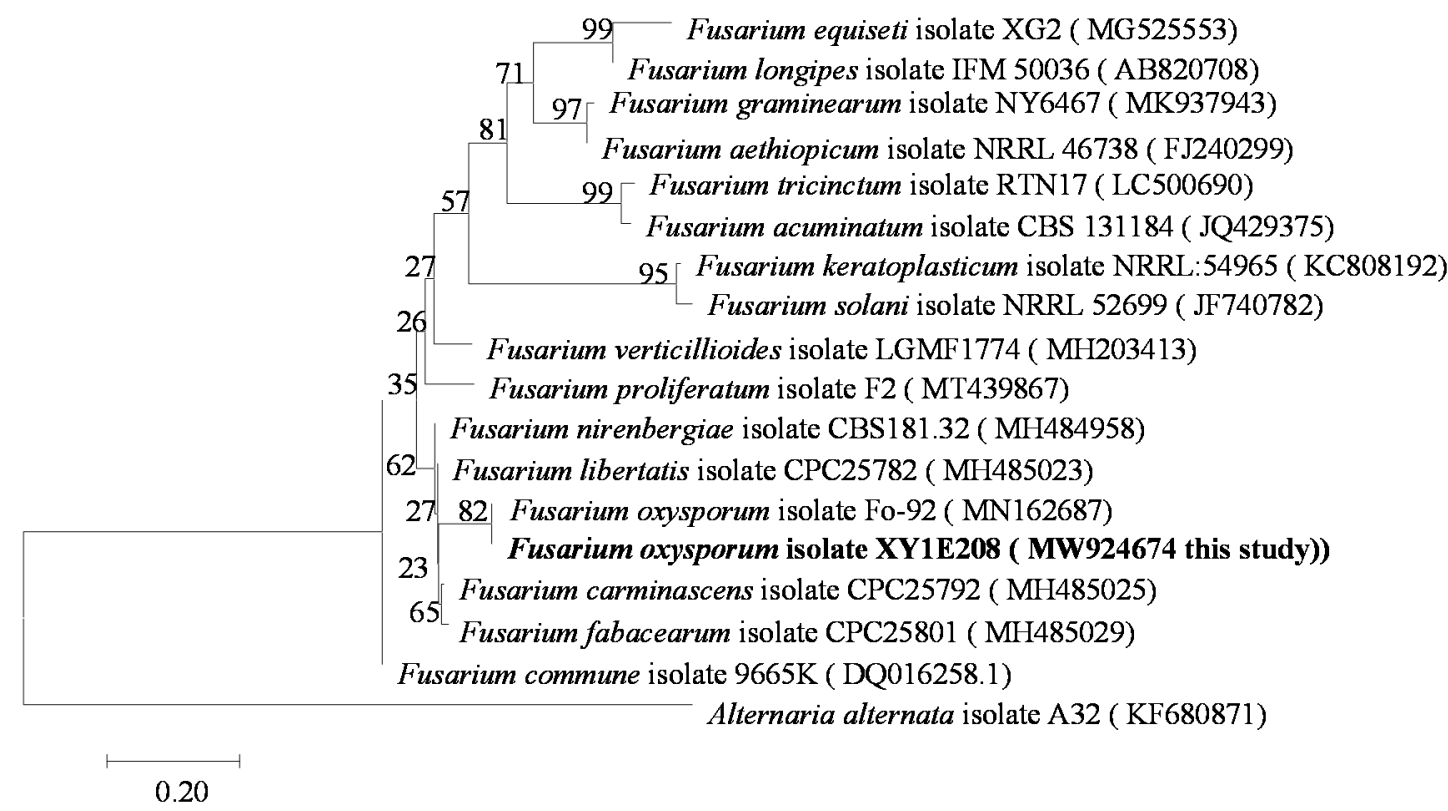

Figure 1. Phylogenetic tree for F. oxysporum based on translation elongation factor- $1 \alpha(T E F-1 \alpha)$ gene sequences.

LAMP primers were designed according to partial TEF-1 $\alpha$ gene sequences as speciesspecific primers with primer explorer V5 software (http:/ / primerexplorer.jp/e/, 13 May 2021). Six LAMP primers are shown in Figure 2 and listed in Table 2, including two external primers (F3 and B3), two internal primers (FIP and BIP), and two loop primers (F-loop and B-loop). The primers were synthesized by Sangon Biological Engineering Co., LTD (Shanghai, China) and then repackaged with $\mathrm{ddH}_{2} \mathrm{O}$ after being dissolved and stored at $4{ }^{\circ} \mathrm{C}$.

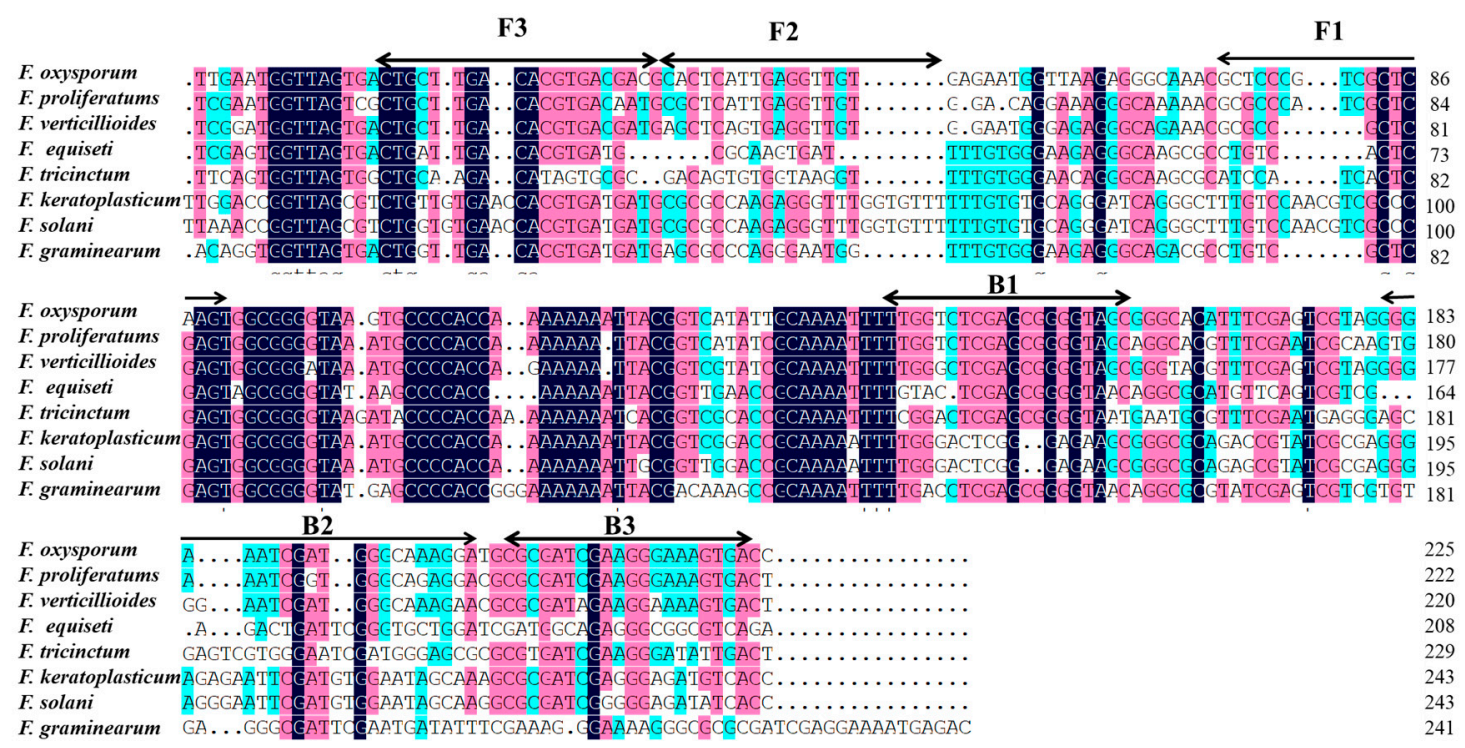

Figure 2. The nucleotide sequence alignment of the translation elongation factor- $1 \alpha(T E F-1 \alpha)$ genes were used to design the LAMP primers. 
Table 2. Primers used for LAMP assays to detect $F$. oxysporum.

\begin{tabular}{ccc}
\hline Primer Name & Sequence $\left.\mathbf{( 5}^{\prime}-\mathbf{3}^{\prime}\right)$ & Length \\
\hline F3 & ACTGCTTGACACGTGACG & 18 \\
B3 & CACTTTCCCTTCGATCGCG & 19 \\
FIP & ACTTACCCCGCCACTTGAGCACGCACTCATTGAGGTTGTG & 40 \\
BIP & TTGGTCTCGAGCGGGGTAGCTCCTTTGCCCATCGATTTCC & 40 \\
LF & CGTTTGCCCTCTTAACCATTCT & 22 \\
LB & GGGCACATTTCGAGTCGTAGG & 21 \\
\hline
\end{tabular}

\subsection{Optimization of LAMP Reaction Conditions}

LAMP reactions were conducted according to Notomi's protocol [29]. The LAMP reactions were accomplished in $200 \mu \mathrm{L}$ microtubes containing $2.5 \mu \mathrm{L}$ of $10 \times$ LAMP Master Mix (New England biolabs (Beijing) LTD., Beijing, China.), $6 \mathrm{mM}$ of $\mathrm{MgSO}_{4}, 1.4 \mathrm{mM}$ of dNTP Mix, $0.2 \mu \mathrm{M}$ of outer primers (F3 and B3), $1.6 \mu \mathrm{M}$ of internal primers (FIP and $\mathrm{BIP}), 0.4 \mu \mathrm{M}$ of loop primers, $320 \mathrm{U} / \mathrm{mL}$ Bst DNA polymerase, $1.0 \mu \mathrm{L}$ DNA template, $3 \mu \mathrm{L}$ of $1000 \times$ diluted SYBR Green I (Sangon Biotech Co., Ltd., Shanghai, China), and autoclaved distilled water was used to adjust the volume to $25 \mu \mathrm{L}$ in the Loopamp RealTime Turbidimeter LA-320C (Eiken Chemical Co., Ltd., Tokyo, Japan). The LAMP reaction conditions were optimized in terms of the concentration of $\mathrm{Mg}^{2+}$, outer primers, and internal primers, temperature, and time of Bst 2.0 DNA polymerase.

For the optimization of reagents, a range of reaction temperatures $(55,58,60,62,64,65$, 66,68 , and $\left.70^{\circ} \mathrm{C}\right)$, a range of reaction times $(15,30,45,60,75$, and $90 \mathrm{~min})$, a range of $\mathrm{Mg}^{2+}$ concentrations $(2,3,4,5,6,7,8,9$, and $10 \mathrm{mM})$, a range of inner primer concentrations $(0.4$, $0.8,1.2,1.6$, and $2 \mu \mathrm{M})$, and a range of outer primer concentrations $(0.2,0.4,0.6,0.8$, and $1 \mu \mathrm{M})$ were evaluated under otherwise identical conditions. The LAMP reactions were performed in $200 \mu \mathrm{L}$ microfuge tubes incubated in a water bath for $60 \mathrm{~min}$ at $65^{\circ} \mathrm{C}$. The reactions were halted by immersion at $80^{\circ} \mathrm{C}$ for $5 \mathrm{~min}$, at which point reaction products were detected by fluorescent LAMP and electrophoresis, following which LAMP reactions were completed. After the LAMP reactions took place, the naked eye color changes were directly observed after adding $3 \mu \mathrm{L} 1000 \times$ SYBR Green I dye and centrifuging at the end of the tube.

\subsection{LAMP Assays Specificity}

Eighteen fungus strains were used for the LAMP specificity test, including strains belonging to the Fusarium genus and other non-Fusarium species (Table 1). The DNA of the tested strains was extracted using a fungal genome DNA isolation kit (Hangzhou Bio-medical technology Co., Ltd. Hangzhou, Zhejiang, China). LAMP reactions were implemented with extracted DNA under optimized conditions. Each experiment was repeated three times.

\subsection{Detection of F. axysporum by LAMP and Conventional PCR}

To evaluate the sensitivity of the LAMP assays, the DNA of Fusarium wilt in D. officinale was extracted and used as a control for LAMP amplification for specific detection. The DNA of $F$. oxysporum was diluted at a range of concentrations $\left(10^{-1}, 10^{-2}, 10^{-3}, 10^{-4}, 10^{-5}, 10^{-6}\right.$, $10^{-7}, 10^{-8}$, and $10^{-9}$ times) as a template for the experiment. The conventional polymerase chain reaction (PCR) mixture contains $1 \mu \mathrm{L}$ of DNA, $1 \mu \mathrm{L}$ of outer primers (F3/B3), $10 \mu \mathrm{L}$ of $2 \times$ Taq Mix DNA polymerase, $7 \mu \mathrm{L}$ of $\mathrm{ddH}_{2} \mathrm{O}$, and $20 \mu \mathrm{L}$ of distilled autoclaved water. The reaction mixtures were incubated in a BIO-RAD TP100 PCR machine. The program was $94{ }^{\circ} \mathrm{C}$ for $5 \mathrm{~min} ; 35$ cycles of $94{ }^{\circ} \mathrm{C}$ for $30 \mathrm{~s}, 56^{\circ} \mathrm{C}$ for $30 \mathrm{~s}, 72{ }^{\circ} \mathrm{C}$ for $1 \mathrm{~min} ; 72{ }^{\circ} \mathrm{C}$ for $10 \mathrm{~min}$.

After a color reaction with fluorescent dye, the $5 \mu \mathrm{L}$ amplification products were detected using electrophoresis with $1 \%$ agarose gel and the molecular weights of bands were determined using DNA molecular weight standards. The products were reacted for $25 \mathrm{~min}$ under conditions of $150 \mathrm{~V}$ and 400A. The gels were photographed under ultraviolet 
light in a gel imaging system after electrophoresis. The existence of ladder bands under ultraviolet light showed that there was soft $\operatorname{rot}$ (F. oxysporum) in the D. officinale samples. However, no ladder bands indicated a negative result.

\subsection{The Feasibility Detection of LAMP Assays}

To evaluate the feasibility of diagnosis by LAMP assays in the field, healthy stems were inoculated with F. oxysporum to simulate field-infected stems and then DNA was extracted from the stems of $D$. officinale and cultivated soil using a fungal genome DNA isolation kit (Hangzhou Biomedical Technology Co., Ltd. Hangzhou, Zhejiang, China) with apparent disease symptoms. The LAMP assays were performed as described above, and non-symptomatic stems of D. officinale and sterilized soil were used as controls. In addition, suspected soft rot of $D$. officinale in six areas of Guizhou province were collected, and LAMP assays could be used to detect pathogens with observations of color changes after adding SYBR Green I.

\subsection{Prevention and Control of F. oxysporum from Soft Rot in D. officinale by LAMP Assays}

Control effects of fungicide combination against $F$. oxysporum were studied in a growth chamber. The pots for planting $D$. officinale were $6.5 \times 8 \mathrm{~cm}(\varphi \times \mathrm{h})$ and filled with nutrient soils, which were inoculated with F. oxysporum following an acupuncture method. The samples of $D$. officinale were detected by LAMP assays before controlling soft rot with a combination of fungicides.

The fungicide combinations were diluted with $0.5 \%$ Tween- 20 water to spray onto D. officinale. Additionally, $10 \mathrm{~mL}$ of fungicide (pyraclostrobin, picoxystrobin, osthole, and physcion) liquid was sprayed onto $D$. officinale after positive detection by LAMP assay. A total of $10 \mathrm{~mL}$ of sterile water was set as the control group. The control effects of fungicide combinations were observed and recorded after spraying for $14 \mathrm{~d}$. The control effect calculation formula is DI $=\left(\sum\right.$ number of diseased leaves (stalks $) \times$ disease grade index) / (the total number of leaves (stalks) $\times$ maximum disease level) $\times 100$. An increased value of the disease index $=$ the DI of leaves $\times 0.5+$ the DI of stalks $\times 0.5$; control effect $(\%)=($ increased value of the disease index in the processing areas-increased value of the disease index in the control areas) / increased value of the disease index in the processing areas $\times 100$.

\section{Results}

\subsection{Identification of Pathogens}

The disease mainly harmed stems of $D$. officinale. In the early stages of this disease, waterlogged disease spots appeared in plant stems. With the development of the disease, damaged areas expanded, leaves became yellow, stems gradually rotted from the bottom up, and finally whole plants wilted (Figure 3A). We collected samples of D. officinale from seven areas of the Guizhou province, isolating and purifying a total of 66 strains, which represented XY1E208 (23 strains of F. oxysporum) (Figure S1). The colonies of strain XY1E208 were circular on PDA medium with hyphae stripes. The aerial hyphae were white, flocculent, and villous. The early colonies were white, and then they changed to a pale purple pigment in the middle of the colonies (Figure 3B). The conidia of F. oxysporum were hyaline, ellipsoidal, unicellular, 1-2 intervals, and ranged from 4.97 to $25.58 \times 1.36$ to $4.33 \mu \mathrm{m}$ in size (Figure 3C). 
A

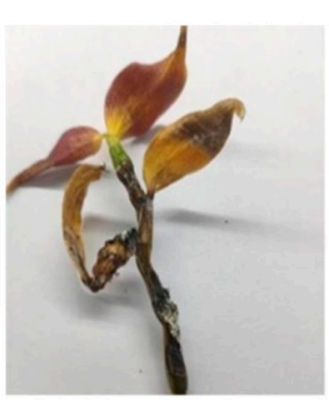

B

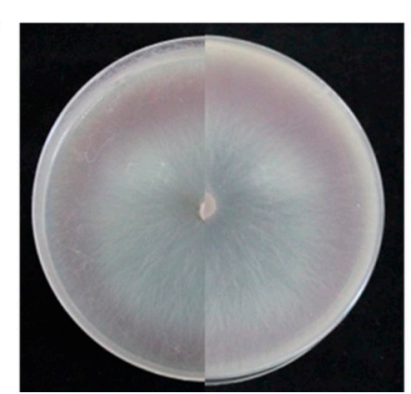

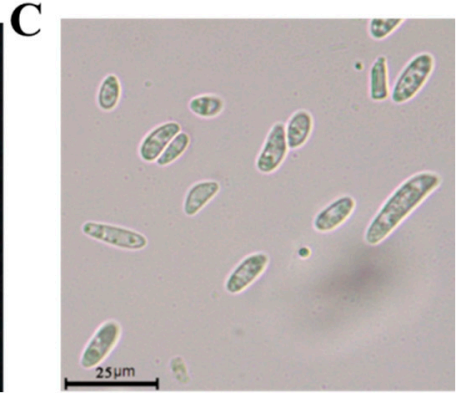

Figure 3. Isolation of pathogenic fungi from soft rot in Dendrobium officinale. (A) $=$ The soft rot on Dendrobium officinale plant in the field; $(\mathbf{B})=$ the morphology of strain XY1E208 after growing on PDA medium for 7 days; $(\mathbf{C})=$ conidia morphology of strain XI1E208.

\subsection{Optimization of LAMP Assays}

In order to find the best LAMP reaction conditions, we carried out many LAMP reactions under different temperatures $\left(55-70{ }^{\circ} \mathrm{C}\right)$, times $(15-90 \mathrm{~min})$, concentrations of $\mathrm{Mg}^{2+}(2-10 \mathrm{mM})$, inner primers $(04-2 \mu \mathrm{M})$, and outer primers $(0.2-1 \mu \mathrm{M})$. The results of SYBR Green I staining showed that the best temperature for LAMP detection of genomic DNA in F. oxysporum was $62^{\circ} \mathrm{C}$ (Figure 4A). After testing at several reaction times, $60 \mathrm{~min}$ was optimal for the LAMP assays for F. oxysporum (Figure 4B). The agarose gel of the ladder bands showed that the reaction had high efficiency with $1.2 \mu \mathrm{M}$ of internal primers (Figure $4 \mathrm{C}$ ), $0.4 \mu \mathrm{M}$ of external primers (Figure $4 \mathrm{D}$ ), and $7 \mathrm{mM} \mathrm{Mg}^{2+}$ (Figure 4E). All LAMP reactions were carried out in a Loopamp RealTime Turbidimeter LA-320C.
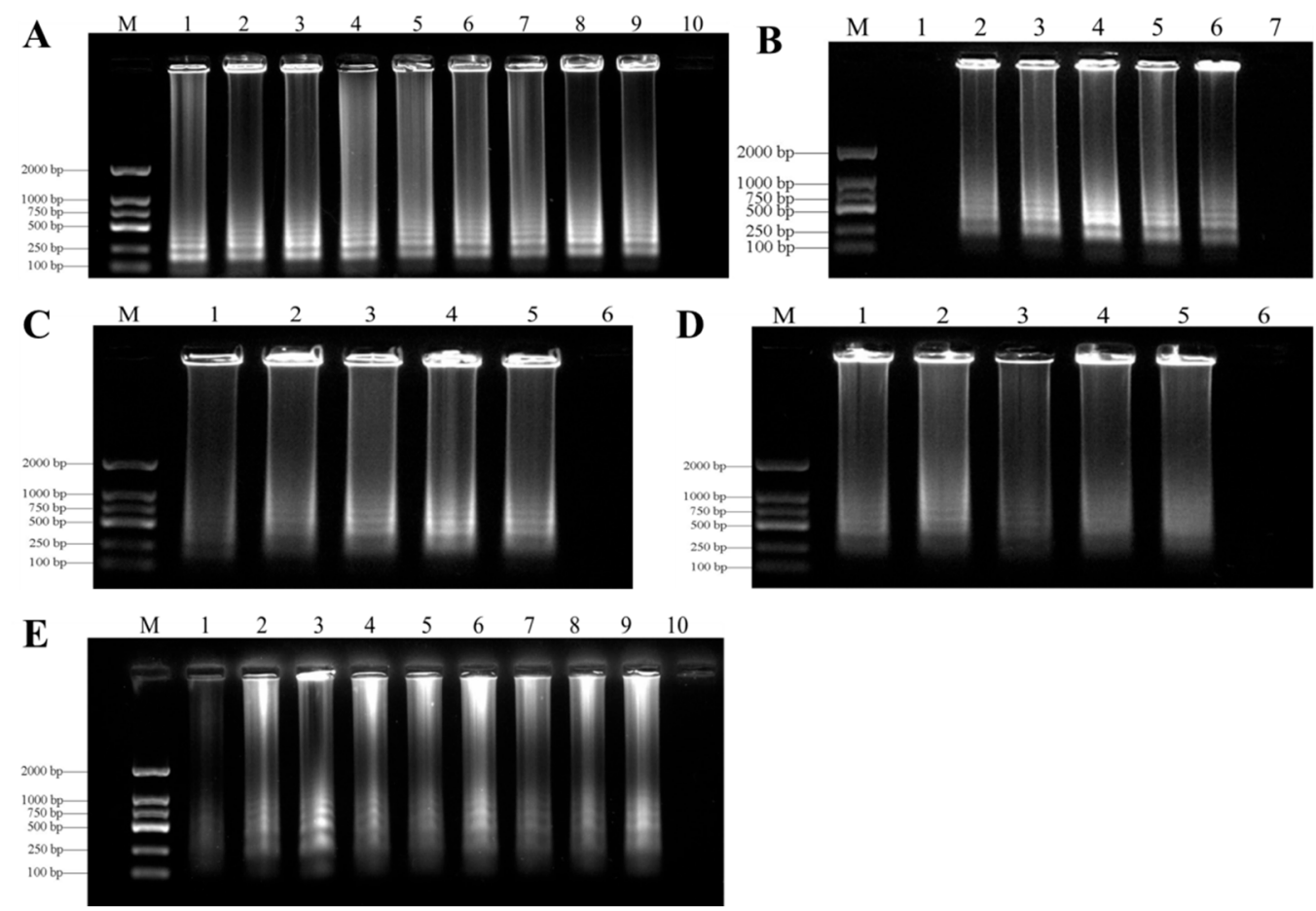

Figure 4. Optimization of LAMP assays. (A) = Optimization of LAMP reaction temperature for detection of F. oxysporum. Lane M, Ds 2000 DNA molecular weight marker ladder; Lane $1,55^{\circ} \mathrm{C}$; Lane 2, $58{ }^{\circ} \mathrm{C}$; Lane 3, $60{ }^{\circ} \mathrm{C}$; Lane $4,62{ }^{\circ} \mathrm{C}$; Lane 5, $64{ }^{\circ} \mathrm{C}$; Lane 6, $65{ }^{\circ} \mathrm{C}$; Lane 7, $66{ }^{\circ} \mathrm{C}$; Lane 8 , $68{ }^{\circ} \mathrm{C}$; Lane $9,70{ }^{\circ} \mathrm{C}$; Lane 10, negative control. (B) = Optimization of LAMP reaction time for detection of F. oxysporum. Lane M, Ds 2000 DNA molecular weight marker ladder; Lane 1, 15 min; Lane 2, $30 \mathrm{~min}$; Lane 3, $45 \mathrm{~min}$; Lane 4, $60 \mathrm{~min}$; Lane 5, $75 \mathrm{~min}$; Lane 6, $90 \mathrm{~min}$; Lane 7, negative control. (C) = Optimization of LAMP reaction inner primer (FIP/BIP) concentration for detection of F. oxysporum. Lane M, Ds 2000 DNA molecular weight marker ladder; Lane 1, $0.4 \mu \mathrm{M}$; Lane 2, $0.8 \mu \mathrm{M}$; 
Lane 3, $1.2 \mu \mathrm{M}$; Lane 4, 1.6 $\mu \mathrm{M}$; Lane 5, $2 \mu \mathrm{M}$; Lane 6, negative control. (D) = Optimization of LAMP reaction outer primer (F3/B3) concentration for detection of F. oxysporum. Lane M, Ds 2000 DNA molecular weight marker ladder; Lane 1, $0.2 \mu \mathrm{M}$; Lane 2, $0.4 \mu \mathrm{M}$; Lane 3, $0.6 \mu \mathrm{M}$; Lane 4, $0.8 \mu \mathrm{M}$; Lane 5, $1 \mu \mathrm{M}$; Lane 6, negative control. (E) = Optimization of LAMP reaction $\mathrm{Mg}^{2+}$ concentrations for detection of F. oxysporum. Lane M, Ds 2000 DNA molecular weight marker ladder; Lane 1, 2 mM; Lane 2, 3 mM; Lane 3, 4 mM; Lane 4, 5 mM; Lane 5, 6 mM; Lane 6, 7 mM; Lane 7, 8 mM; Lane 8, $9 \mathrm{mM}$; Lane 9, $10 \mathrm{mM}$; Lane 10, negative control.

\subsection{Specificity of LAMP Assays}

LAMP specificity was determined with genome DNA from F. oxysporum and other pathogens through direct visual observation after adding SYBR Green I stain (Table 1). After the reaction, positive samples of color turned green but the color of negative samples remained orange. LAMP primers of F. oxysporum based on TEF-1 $\alpha$ amplification yielded positive reactions when testing for DNA, while the DNA from other pathogens were used as negative controls (Figures 5 and S2).

A
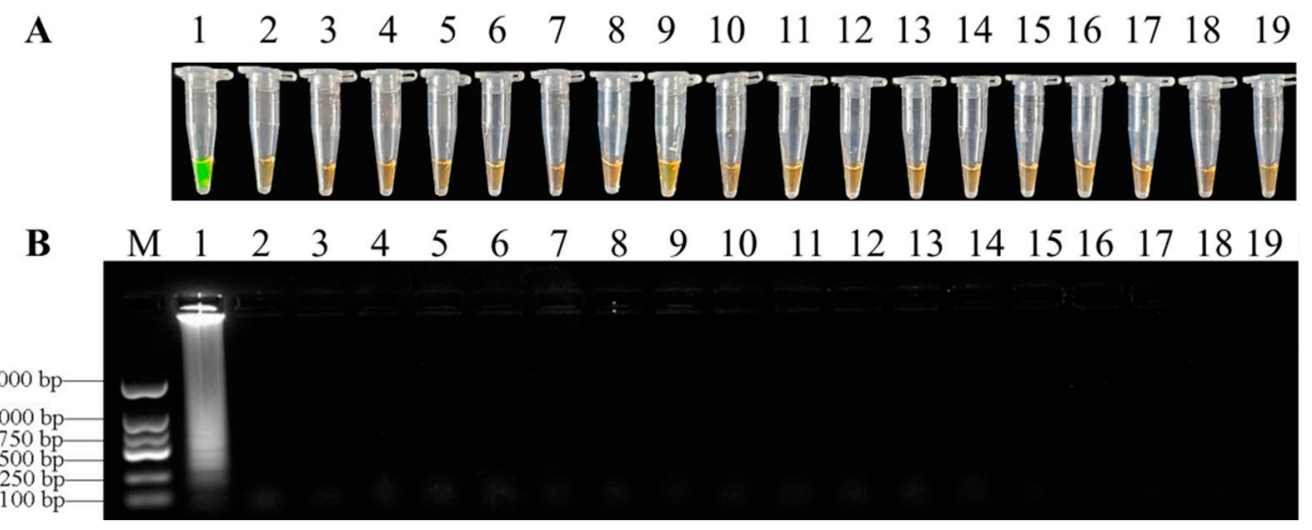

Figure 5. Specificity of LAMP detection of F. oxysporum. (A) = Assessment based on SYBR Green I visualization of color change; (B) = LAMP products analyzed by agarose gel electrophoresis. 1, Fusarium xysporum; 2, Fusarium proliferatum; 3, Fusarium equiseti; 4, Fusarium solani; 5, Fusarium chlamydosporum; 6, Fusarium fujikuroi; 7, Fusarium graminearum; 8, Colletotrichum fructicola; 9, Epicoccum sorghinum; 10, Neurospora sitophila; 11, Lasiodiplodia pseudotheobromae; 12, Trichoderma harzianum; 13, Botryosphaeria dothidea; 14, Phomopsis sp.; 15, Pythium ultimum; 16, Magnaporthe oryzae; 17, Rhizoctonia solani; 18, Botrytis cinerea; 19 , double-distilled water as negative control.

\subsection{Sensitivities of LAMP and Conventional PCR Assays}

The limits of the LAMP assays were evaluated with a series of concentrations $\left(10^{-1}\right.$ $10^{-9} \mathrm{ng} / \mu \mathrm{L}$ ) of F. oxysporum DNA template based on partial TEF-1 $\alpha$ gene sequences under optimized reaction conditions. The limit of LAMP assays was $5 \mathrm{fg} / \mu \mathrm{L}$ for the genomic DNA of F. oxysporum in D. officinale (Figure 6A,B). However, the sensitivity of conventional PCR was every $25 \mu \mathrm{L}$ system of F. oxysporum DNA purified by $5 \mathrm{pg} / \mu \mathrm{L}$ (Figure $6 \mathrm{C}$ ). Therefore, the LAMP assays were more sensitive than conventional PCR assays.

A

B

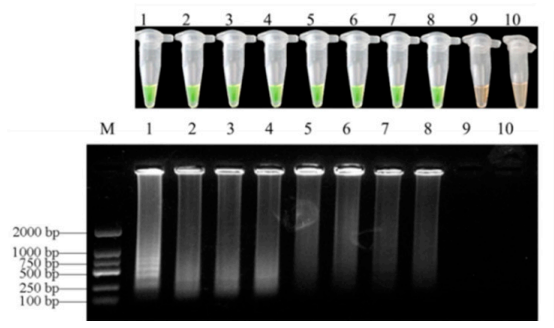

C

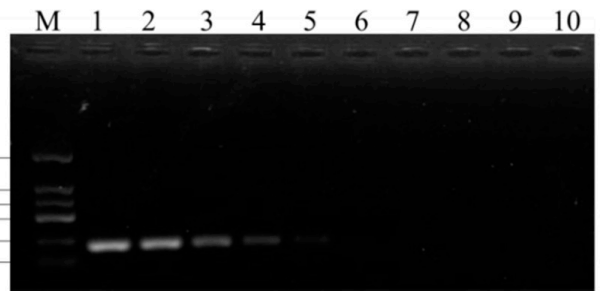

Figure 6. Sensitivity of LAMP and conventional PCR for detection F. oxysporum genomic DNA. 
(A) = Detection by LAMP with SYBR Green I staining; (B) = LAMP products analyzed by agarose gel electrophoresis; $(\mathbf{C})=$ conventional PCR analyzed on gel electrophoresis. The sensitivities of these assays were evaluated using serially diluted genomic DNA as follows: $1,50 \mathrm{ng} / \mu \mathrm{L} ; 2,5 \mathrm{ng} / \mu \mathrm{L} ; 3$, $0.5 \mathrm{ng} / \mu \mathrm{L} ; 4,50 \mathrm{pg} / \mu \mathrm{L} ; 5,5 \mathrm{pg} / \mu \mathrm{L} ; 6,0.5 \mathrm{pg} / \mu \mathrm{L} ; 7,50 \mathrm{fg} / \mu \mathrm{L} ; 8,5 \mathrm{fg} / \mu \mathrm{L} ; 9,0.5 \mathrm{fg} / \mu \mathrm{L} ; 10$, negative control. M, DL 2000 DNA marker.

\subsection{The Feasibility Detection of LAMP Assays}

All disease samples and inoculated samples of $D$. officinale were detected by LAMP assays. Our search results showed that LAMP products of positive reactions turned green after mixing with SYBR Green I while products of samples without infection remained orange (Figure 7). After observing significant symptoms, eight samples were detected to be positive of nine samples from infected tissues by LAMP assays (Figure 7). Seven samples were also positive of nine soil samples (Figure 7B). In addition, six suspected samples of soft rot in D. officinale collected from the Guizhou province in the field were all positive when using LAMP assays (Figure 7C). As a result, the LAMP assays could be used for detecting directly diseased samples of F. oxysporum in D. officinale, and further used for rapid diagnosis of the disease in the field.

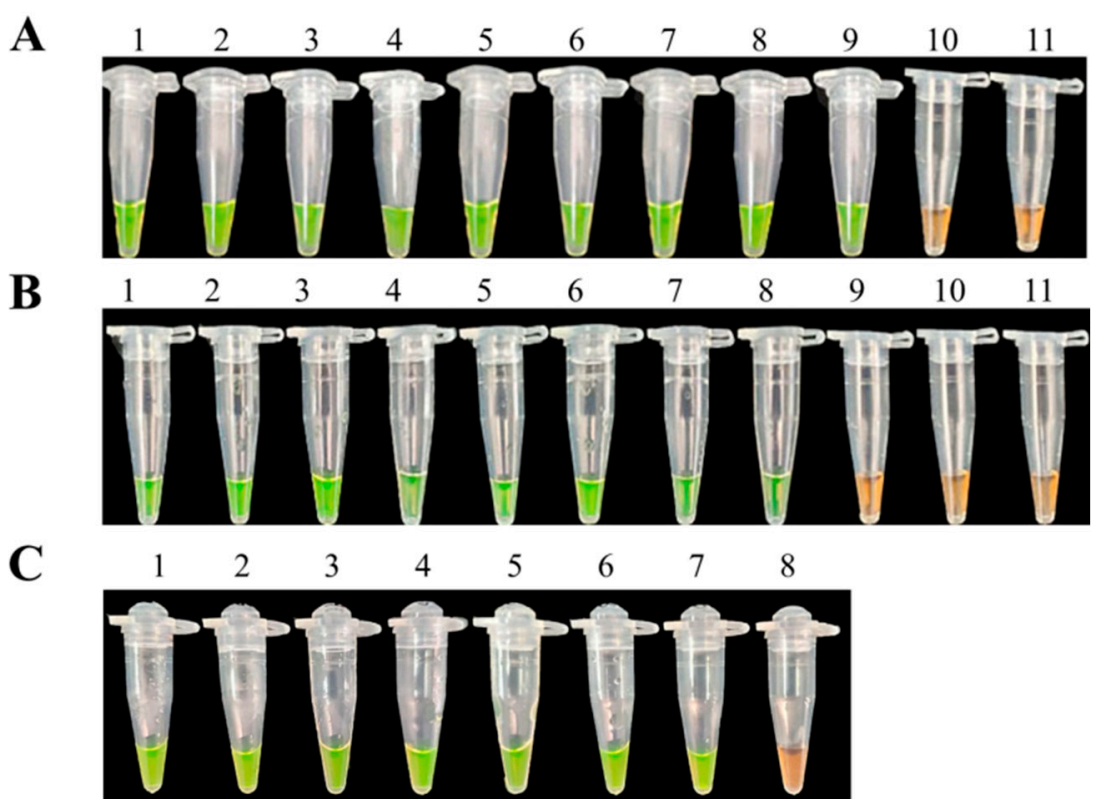

Figure 7. The feasibility detection of the LAMP assay. LAMP reactions were inspected by adding SYBR Green I dye. (A) = LAMP detection of F. oxysporum from tissues after infection: 1, purified genomic DNA of F. oxysporum (positive control); 2-10, DNA from D. officinale stems infected by $F$. oxysporum; 11, DNA from healthy D. officinale stems (negative control); $(\mathbf{B})=$ LAMP detection of $F$. oxysporum from soil after infection: 1, purified genomic DNA of F. oxysporum (positive control); 2-10, DNA extracted from soil after infection; 11, DNA from sterilized soil (negative control); (C) = LAMP detection of field issues: 1, purified genomic DNA of F. oxysporum (positive control); 2-7, DNA extracted from field issues; 8, DNA from healthy D. officinale stems (negative control).

\subsection{Prevention and Control of Soft Rot in D. officinale by LAMP Assays}

We used 21 pots of $D$. officinale plants artificially planted with an average plant height of $15 \mathrm{~cm}$ in this pot experiment. After pathogenic back grafting with F. oxysporum, 12 samples were randomly selected for LAMP testing before disease symptoms appeared. Three samples showed positive results among 12 random samples (Figure 8A). However, 10 samples showed positive results among 12 random samples after disease symptoms appeared (Figure 8B). Then, we immediately sprayed our samples with fungicides in a synergistic combination to control the soft rot in D. officinale plants after most samples 
tested positive via LAMP assays. The control effects of fungicide synergism combinations (pyraclostrobin and picoxystrobin, osthole and physcion) against soft rot were higher than $75.00 \%$ after spraying for 14 days, with control effects being 82.39 and $76.74 \%$, respectively (Table 3). Thus, the LAMP assays can be used for detecting directly diseased samples of $F$. oxysporum in D. officinale.

A

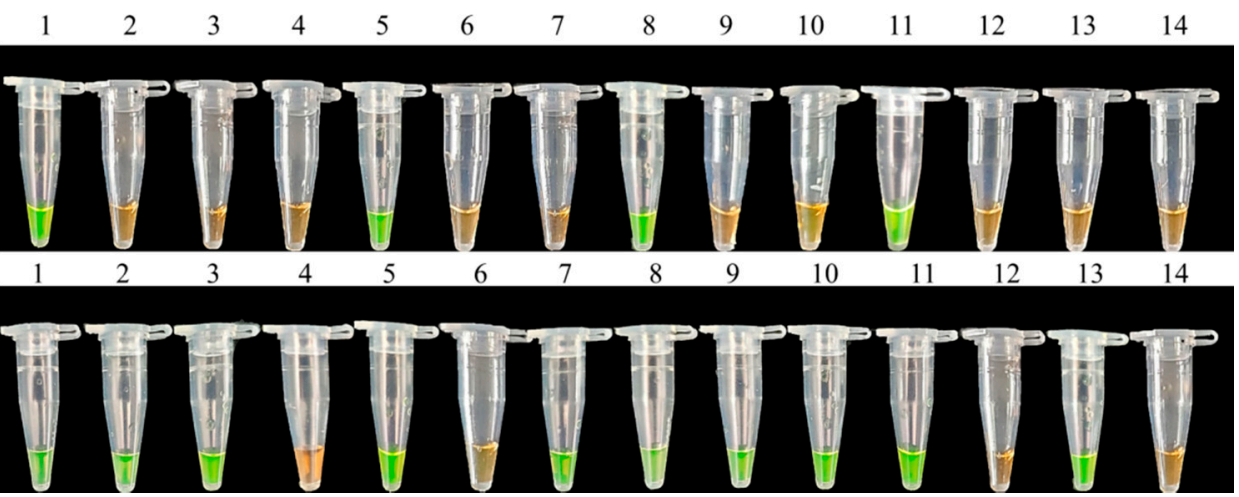

Figure 8. LAMP assay random sampling detection of F. oxysporum in potted plants of D. officinale before pesticide control. (A) = LAMP assay to detect F. oxysporum in potted plants of D. officinale from random samples before the symptoms of soft rot were exposed in pots: 1, purified genomic DNA of F. oxysporum (positive control); 2-13, DNA from D. officinale stems before the symptoms of soft rot were exposed in pots; 11, DNA from healthy D. officinale stems (negative control); (B) = LAMP assay to detect $F$. oxysporum in potted plants of D. officinale from random samples after the symptoms of soft rot were exposed in pots: 1, purified genomic DNA of F. oxysporum (positive control); 2-13, DNA from $D$. officinale stems after the symptoms of soft rot were exposed in pots; 11 , DNA from healthy $D$. officinale stems (negative control).

Table 3. Effect of fungicide synergism combinations against soft rot in D. officinale.

\begin{tabular}{ccccc}
\hline Treatment & $\begin{array}{c}\text { Concentration } \\
\left(\mathbf{g} \text { a.i././.m } \mathbf{~}^{\mathbf{~}}\right.\end{array}$ & $\begin{array}{c}\text { Average Disease } \\
\text { Index before } \\
\text { Spraying } \\
\text { Fungicide }\end{array}$ & $\begin{array}{c}\text { Average Disease } \\
\text { Index 14 Days } \\
\text { after Spraying } \\
\text { Fungicide }\end{array}$ & $\begin{array}{c}\text { Control Efficacy } \\
\mathbf{( \% )}\end{array}$ \\
\hline CK & $/$ & 32.08 & 87.41 & $/$ \\
Pyraclostrobin(A) & 4.9635 & 35.83 & 44.44 & $84.25 \mathrm{a}$ \\
Picoxystrobin(B) & 11.0865 & 43.47 & 55.65 & $78.07 \mathrm{c}$ \\
A:B(1:3) & 4.128 & 47.78 & 57.5 & $79.29 \mathrm{bc}$ \\
Osthole(C) & 16.839 & 41.59 & 53.06 & $66.47 \mathrm{~d}$ \\
Physcion(D) & 192.3 & 35.65 & 54.21 & $76.74 \mathrm{c}$ \\
C:D(7:1) & 18.195 & 38.33 & 51.11 & $\mathrm{~b}$ \\
\hline
\end{tabular}

Note: Different lowercase letters in the same column show significant difference at 0.05 level by Duncan's multiple range test.

\section{Discussion}

The soft rot in D. officinale caused by F. oxysporum is one of the main diseases in the productive areas of China. This pathogen harms plants' roots, causing vascular bundle disease and plant death, which can occur along the entire growth period of D. officinale, resulting in great losses to production [39-42]. The seriously damaged crops reported at home and abroad are eggplant, sugarcane, blackberry, cotton, etc. [43-46]. At present, chemical control is also the most common method to control plant diseases. However, the effect is often not ideal due to F. oxysporum being a soil-borne disease [47-49]. Thus, it is essential to develop an early and rapid diagnostic method for soft rot (F. oxysporum) in D. officinale for proper and timely disease control. In this study, when F. oxysporum primers showed positive reactions in LAMP detection assays, it could predict occurrences of the disease, which is sufficient evidence to guide further control of soft rot in D. officinale. 
TEF-1 $\alpha$ is a highly conserved and ubiquitous protein, which has been widely used to study intra- and inter-species variation and phylogeny in the Fusarium genus [50,51]. Therefore, the TEF- $1 \alpha$ region is suitable as a target for the design of LAMP primers. The results of this study also show that the designed primers were highly specific to F. oxysporum, thus LAMP detection could correctly distinguish F. oxysporum from a variety of Fusarium spp.

Our study showed that LAMP assays could correctly detect F. oxysporum. Compared with a conventional PCR assay, the LAMP assays were fast and simple because LAMP reactions are carried out under constant temperature conditions without a thermal circulator. The results of the LAMP assays can be visualized after adding SYBR Green I or Calcein without gel electrophoresis [52,53]. In our study, we used SYBR Green I dye, which showed a clear color change from orange to green to indicate a positive reaction. We also rapidly developed LAMP assays to successfully identify F. oxysporum in D. officinale with a detection limit of $5 \mathrm{fg} / \mu \mathrm{L}$ (Figure $5 \mathrm{~A}$ ), which was significantly higher than previous studies and more sensitive than conventional PCR tests $[54,55]$. The difference in detection limits by LAMP assays may be due to different sequences as targets in reactions [56]. Therefore, the optimization of a LAMP detection system is very important.

The LAMP method can detect plant pathogens based on the amplification of target DNA sequences $[57,58]$. We detected various specimens by extracting DNA from different types of samples, including hyphae, infected tissue of D. officinale and soil, and suspected samples in the field. Our search results indicated that LAMP assays could be used to directly detect F. oxysporum in diseased samples. These results were consistent with previous studies using LAMP assays [59,60]. The LAMP assays could detect the samples of F. oxysporum from plant tissues and soil, confirming that this method could be used to diagnose soft rot of F. oxysporum in D. officinale.

Previous studies have reported that external spores have been dispersed by wind, water, people, equipment, and the movement of soil particles as they contain the fungus [61]. Therefore, it is important to prevent and control Fusarium wilt, which is maintained in environmental conditions. In this study, we have established a method to rapidly detect $F$. oxysporum that also provides early diagnosis of various diseases caused by F. oxysporum. Combined with results of detection by LAMP assays, we may find more accurate and effective pesticides in order to rapidly bring infection under control.

\section{Conclusion}

In this study, a LAMP method for the detection of F. oxysporum was established. The LAMP assays of F. oxysporum were reacted for $60 \mathrm{~min}$ at $62^{\circ} \mathrm{C}$ with $1.2 \mu \mathrm{M}$ internal primers, $0.4 \mu \mathrm{M}$ external primers, and $7 \mathrm{mM} \mathrm{Mg}^{2+}$, while the PCR method would usually have taken $2-6 \mathrm{~h}$. Based on the TEF-1 $\alpha$ gene sequence, designed primers were highly specific for F. oxysporum, with a detection limit of $5 \mathrm{fg} / \mu \mathrm{L}$ through visual inspection after SYBR Green I staining, which was significantly more sensitive than a conventional PCR test $(5 \mathrm{pg} / \mu \mathrm{L})$. Thus, LAMP assays can be used as an effective tool for the early diagnosis of soft rot ( $F$. oxysporum) in D. officinale in the field for proper and timely disease control.

Supplementary Materials: The following are available online at https: / www.mdpi.com/article / 10.3390/biology10111136/s1: Figure S1: Phylogenetic tree for 23 strains of F. oxysporum based on internal transcribed spacer (ITS) gene sequences; Figure S2: Sensitivity of LAMP and conventional PCR for detection of genomic DNA in F. oxysporum. (A) Detection by LAMP with SYBR Green I staining; (B) LAMP products analyzed by agarose gel electrophoresis. 1, XY1E208; 2, XY1; 3, XY1A; 4, XY1C; 5, XY1K; 6, XY3; 7, SJ-3; 8, SJ-4; 9,SS-YP-1-2; 10, TG-3-1; 11, TG-3-2; 12, TG-4-1; 13, WSS-2; 14, WSS-7.;15, AL2-2; 16, AL2-3; 17, AL3-1; 18, AL3-3; 19, AL3-4; 20, AL5; 21, AL6-1; 22, AL6-2; 23, AL6-3; 24, double-distilled water as negative control.

Author Contributions: Conceptualization, R.L.; methodology and formal analysis, C.X.; funding acquisition, R.L.; writing-review and editing, C.X. and R.L.; visualization, R.L. All authors have read and agreed to the published version of the manuscript. 
Funding: This work was supported by the National Natural Science Foundation of China (No. $32160657,31701816)$, agricultural research projects of the science and technology department of the Guizhou province (No. [2019]3001), and the cultivation project of Guizhou university (No. [2019]43).

Institutional Review Board Statement: Not applicable.

Informed Consent Statement: Not applicable.

Data Availability Statement: Sequencing data are available from https:/ / www.ncbi.nlm.nih.gov/ nuccore/MW924674.

Acknowledgments: The authors thank Li, R.Y. for her help with the statistical analyses and the methodology.

Conflicts of Interest: The authors declare no conflict of interest.

\section{References}

1. Ge, D.; Li, X.; Ding, X.; Qian, L. Genetic diversity across natural populations of Dendrobium officinale, the endangered medicinal herb endemic to China, revealed by ISSR and RAPD markers. Russ. J. Genet. 2009, 45, 327-334. [CrossRef]

2. Jin, Z.; Li, D.; Liu, T.; Yu, F.; Liu, Z. Cultural endophytic fungi associated with Dendrobium officinale: Identification, diversity estimation and their antimicrobial potential. Curr. Sci. 2017, 112, 1690-1697. [CrossRef]

3. Luo, Q.L.; Tang, Z.H.; Zhang, X.F.; Zhong, Y.H.; Yao, S.Z.; Wang, L.S.; Lin, C.W.; Luo, X. Chemical properties and antioxidant activity of a water-soluble polysaccharide from Dendrobium officinale. Int. J. Biol. Macromol. 2016, 89, 219-227. [CrossRef] [PubMed]

4. Chen, W.H.; Wu, J.J.; Li, X.F.; Lu, J.M.; Wu, W.; Sun, Y.Q.; Zhu, B.; Qin, L.P. Isolation, structural properties, bioactivities of polysaccharides from Dendrobium officinale Kimura et. Migo: A review. Int. J. Biol. Macromol. 2021, 184, 1000-1013. [CrossRef]

5. Liu, X.F.; Zhu, J.; Ge, S.Y.; Xia, L.J.; Ren, F.Z. Orally Administered Dendrobium officinale and its Polysaccharides Enhance Immune Functions in BALB/c Mice. Nat. Prod. Commun. 2011, 6, 867-870. [CrossRef] [PubMed]

6. Liu, J.J.; Liu, Z.P.; Zhang, X.F.; Si, J.P. Effects of Various Processing Methods on the Metabolic Profile and Antioxidant Activity of Dendrobium catenatum Lindley Leaves. Metabolites 2021, 11, 351. [CrossRef]

7. Li, G.; Li, R.Y.; Gao, W.W. Occurrence situation and control strategy of Dendrobium diseases in large-scale farming system. China J. Chin. Mater. Med. 2013, 38, 485.

8. Guo, M.; Li, B.; Wang, R.; Liu, P.; Chen, Q. Occurrence of dieback disease caused by Fusarium equiseti on Dendrobium officinale in China. Crop. Prot. 2020, 137, 105209. [CrossRef]

9. Vellupillai, S.; Jin, G. Histological and protein changes during early stages of seed germination in the orchid, Dendrobium crumenatum. J. Hortic. Sci. 1997, 72, 941-948. [CrossRef]

10. Ng, T.B.; Liu, J.Y.; Wong, J.H.; Ye, X.J.; Wing Sze, S.C.; Tong, Y.; Zhang, K.Y. Review of research on Dendrobium, a prized folk medicine. Appl. Microbiol. Biotechnol. 2012, 93, 1795-1803. [CrossRef]

11. Lin, X.; Zhou, Y.; Zhong, J.; Zhu, J.; Chen, X.; Lin, Y.; Huang, M.; Yang, L.; Zhang, Z. Imitated Ecological Cultivation Technology of Dendrobium offcinale: A Case Study of Longshitou Village, Longmen County. Plant. Dis. Pests 2021, 12, 24-26. [CrossRef]

12. Chen, L.; Zhang, H.; Liang, D.; Peng, H.; Huang, C.; Zhou, Z.; Liao, Y.; Lin, D. Wild cultivation technology of Dendrobium officinale in natural secondary forest in northern Guangdong Province. South. China For. Sci. 2018, 46, 48-50. [CrossRef]

13. Tang, L.M.; Chen, Y.F.; Dai, Q.; Li, D.Y.; Jiang, L.; Deng, Y.H. The Standardized Technology Demonstration of Cultivating Dendrobium officinale Kimura et Migo under Forest. Anhui Agric. Sci. Bull. 2015, 21, 45-53. [CrossRef]

14. Guan, Y.J.; Li, L.R.; Liu, S.D. Effects of Meteorological Conditions on the Growth of Dendrobium candidum under Forest. Sci. Technol. Eng. 2018, 18, 200-203.

15. Oren, L.; Ezrati, S.; Cohen, D.; Sharon, A. Early events in the Fusarium verticillioides-maize interaction characterized by using a green fluorescent protein-expressing transgenic isolate. Appl. Environ. Microbiol. 2003, 69, 1695-1701. [CrossRef]

16. Olivain, C.; Humbert, C.; Nahalkova, J.; Fatehi, J.; L'Haridon, F.; Alabouvette, C. Colonization of tomato root by pathogenic and nonpathogenic Fusarium oxysporum strains inoculated together and separately into the soil. Appl. Environ. Microbiol. 2006, 72, 1523-1531. [CrossRef] [PubMed]

17. Lagopodi Anastasia, L.; Ram Arthur, F.J.; Lamers, G.E.M.; Punt, P.J.; Van den Hondel, C.A.M.J.J. Novel aspects of tomato root colonization and infection by Fusarium oxysporum f. sp. radicis-lycopersici revealed by confocal laser scanning microscopic analysis using the green fluorescent protein as a marker. Mol. Plant.-Microbe Interact. 2002, 15, 172-179. [CrossRef]

18. Eynck, C.; Koopmann, B.; Grunewaldt-Stoecker, G.; Karlovsky, P.; Tiedemann, A.V. Differential interactions of Verticillium longisporum and $V$. dahliae with Brassica napus detected with molecular and histological techniques. Eur. J. Plant. Pathol. 2007, 118, 259-274. [CrossRef]

19. Zhou, L.; Hu, Q.; Johansson, A.; Dixelius, C. Verticillium longisporum and V. dahliae: Infection and disease in Brassica napus. Plant. Pathol. 2006, 55, 137-144. [CrossRef]

20. Herman, R.; Zvirin, Z.; Kovalski, I.; Freeman, S.; Denisov, Y.; Zuri, G.; Katzir, N.; Perl-Treves, R.; Pitrat, M. Characterization of Fusarium race 1.2 resistance in melon and mapping of a major QTL for this trait near a fruit netting locus. In Proceedings of the IXth EUCARPIA Meeting on Genetics and Breeding of Cucurbitaceaee, Avignon, France, 21-24 May 2008; pp. 149-156. [CrossRef] 
21. Song, H.H.; Lee, H.S.; Jeong, J.H.; Park, H.S.; Chan, L. Diversity in Beauvericin and Enniatins H, I, and MK1688 by Fusarium oxysporum isolated from potato. Int. J. Food Microbiol. 2008, 122, 296-301. [CrossRef]

22. Son, S.W.; Kim, H.Y.; Choi, G.J.; Lim, H.K.; Jang, K.S.; Lee, S.O.; Lee, S.; Sung, N.D.; Kim, C.J. Bikaverin and fusaric acid from Fusarium oxysporum show antioomycete activity against Phytophthora infestans. J. Appl. Microbiol. 2008, 104, 692-698. [CrossRef]

23. Waskiewicz, A.; Golinski, P.; Karolewski, Z.; Irzykowska, L.; Weber, Z. Formation of fumonisins and other secondary metabolites by Fusarium oxysporum and F. proliferatum: A comparative study. Food Addit. Contam. Part A 2010, 27, 608-615. [CrossRef]

24. Zaccardelli, M.; Spasiano, A.; Bazzi, C.; Merighi, M. Identificationand in planta detection of Pseudomonas syringae pv tomatousing PCR amplification of hrpZpst. Eur. J. Plant. Pathol. 2005, 111, 85-90. [CrossRef]

25. George, J.R.; Vanneste, J.L.; Cornish, D.A.; Pushparajah, I.P.S.; Yu, J.; Templeton, M.D.; Everett, K.R. Detection of Pseudomonas syringae pv. actinidiae using polymerase chain reaction (PCR) primers based on the 16S-23S rDNA inter transcribed spacer region and comparison with PCR primers based on other gene regions. Plant. Pathol. 2010, 59, 453-464. [CrossRef]

26. Niessen, L.; Luo, J.; Denschlag, C.; Vogel, R.F. The application of loop-mediated isothermal amplification (LAMP) in food testing for bacterial pathogens and fungal contaminants. Food Microbiol. 2013, 36, 191-206. [CrossRef] [PubMed]

27. Lu, T.F.; Tao, L.Y.; Yu, H.B.; Zhang, H.; Wu, Y.J.; Wu, S.G.; Zhou, J. Development of a reverse transcription loop mediated isothermal amplification assays for the detection of Mouse reovirus type 3 in laboratory mice. Sci. Rep. 2021, 11, 3508. [CrossRef] [PubMed]

28. Yao, J.A.; Huang, P.; Hou, X.Y.; Yu, D.Y. Rapid detection by a loop-mediated isothermal amplification assays based on EF-1 $\alpha$ gene for stem rot on Cymbidium ensifolium. Eur. J. Hortic. Sci. 2021, 86, 212-218. [CrossRef]

29. Notomi, T.; Okayama, H.; Masubuchi, H.; Yonekawa, T.; Watanabe, K.; Amino, N.; Hase, T. Loop-mediated isothermal amplification of DNA. Nucleic Acids Res. 2000, 28, 63. [CrossRef] [PubMed]

30. Iwamoto, T.; Sonobe, T.; Hayashi, K. Loop-Mediated Isothermal Amplification for Direct Detection of Mycobacterium tuberculosis Complex, M. avium, and M. intracellulare in Sputum Samples. J. Clin. Microbiol. 2003, 41, 2616-2622. [CrossRef]

31. Duan, Y.B.; Yang, Y.; Wang, J.X.; Liu, C.C.; He, L.L.; Zhou, M.G. Development and application of loop-mediated isothermal amplification for detecting the highly benzimidazole-resistant isolates in Sclerotinia sclerotiorum. Sci. Rep. 2015, 5, 17278. [CrossRef] [PubMed]

32. Mori, Y.; Notomi, T. Loop-mediated isothermal amplification (LAMP): A rapid, accurate, and cost-effective diagnostic method for infectious diseases. J. Infect. Chemother. 2009, 15, 62-69. [CrossRef]

33. Verma, S.; Avishek, K.; Sharma, V.; Negi, N.S.; Ramesh, V.; Salotra, P. Application of loop-mediated isothermal amplification assays for the sensitive and rapid diagnosis of visceral leishmaniasis and post-kala-azar dermal leishmaniasis. Diagn. Microbiol. Infect. Dis. 2013, 75, 390-395. [CrossRef] [PubMed]

34. Hara, K.Y.; Yoshino, M.; Kojima, T.; Ikedo, M. Loop-mediated isothermal amplification for the rapid detection of Salmonella. Fems Microbiol. Lett. 2010, 253, 155-161. [CrossRef]

35. Nirenberg, H.I.; O'Donnell, K. New Fusarium species and combinations within the Gibberella fujikuroi species complex. Mycologia 1998, 90, 434-458. [CrossRef]

36. Taylor, J.W.; Jacobson, D.J.; Fisher, M.C. The evolution of asexual fungi: Reproduction, Speciation and Classification. Immunology 1999, 121, 383-391. [CrossRef]

37. Amatulli, M.; Spadaro, D.; Gullino, M.L.; Garibaldi, A. Corrigendum: Molecular identification of Fusarium spp. associated with bakanae disease of rice in Italy and assessment of their pathogenicity. Plant. Pathol. 2012, 61, 820. [CrossRef]

38. White, T.; Bruns, T.; Lee, S.; Taylor, F.; White, T.J.; Lee, S.H.; Taylor, L.; Shawe-taylor, J. Amplification and direct sequencing of fungal ribosomal RNA genes for phylogenetics. In PCR Protocols; Academic Press: San Diego, CA, USA, 1990 ; pp. 315-322. [CrossRef]

39. Li, H.S.; Ye, W.; Wang, Y.; Chen, X.H. RNA sequencing-based exploration of the effects of far-red light on lncRNAs involved in the shade-avoidance response of D. officinale. PeerJ 2021, 9, e10769. [CrossRef]

40. Zhang, M.Z.; Yu, Z.M.; Zeng, D.Q.; Si, C. Transcriptome and Metabolome Reveal Salt-Stress Responses of Leaf Tissues from Dendrobium officinale. Biomolecules 2021, 11, 736. [CrossRef]

41. Almasi, M.A. Development of A Colorimetric Loop-Mediated Isothermal Amplification Assays for the Visual Detection of Fusarium oxysporum f.sp. melonis. Hortic. Plant. J. 2019, 5, 41-48. [CrossRef]

42. Shamsher, A.; Hasmi, S.K.; Aftab, M.A.; Khan, R.U. Biological Management of Chrysanthemum Wilt (Fusarium oxysporum f.sp. chrysanthemi. Int. J. Curr. Microbiol. Appl. Sci. 2020, 9, 639-644. [CrossRef]

43. Zhang, J.; Li, T.; Cai, Y.F.; Wang, Y.Z. Genetic and environmental effects on allometry of the medicinal plant Dendrobium officinale (Orchidaceae) from Yunnan, southwest China. Pak. J. Bot. 2021, 53, 1675-1682. [CrossRef]

44. Bao, Y.X.; Sun, H.J.; Li, Y.F.; Duan, Z.Z.; McCord, P.H.; Cui, Y.P.; Zhang, M.Q. First Report of Fusarium oxysporum isolate gx3 Causing Sugarcane Pokkah Boeng in Guangxi of China. Plant. Dis. 2016, 100, 1785. [CrossRef]

45. Pastrana, A.M.; Cline, W.; Wong, T.W.; Watson, D.C.; Mercier, J.; Ivors, K.; Broome, J.C.; Quesada-Ocampo, L.M.; Gordon, T.R. First report of Fusarium Wilt of Blackberry Caused by Fusarium oxysporum f. sp. mori in North Carolina. Plant. Dis. 2019, 104, 971. [CrossRef]

46. Zhu, Y.; Lujan, P.; Wedegaertner, T.; Nichols, R.L.; Sanogo, S. First Report of Fusarium oxysporum f. sp. vasinfectum Race 4 Causing Fusarium Wilt of Cotton in New Mexico, U.S.A. Plant. Dis. 2020, 104, 588. [CrossRef] 
47. Bowers, J.H.; Locke, J.C. Effect of Botanical Extracts on the Population Density of Fusarium oxysporum in Soil and Control of Fusarium Wilt in the Greenhouse. Plant. Dis. 2000, 84, 300-305. [CrossRef] [PubMed]

48. Cal, A.D.; Pascual, S.; Larena, I.; Melgarejo, P. Biological control of Fusarium oxysporum f. sp. lycopersici. Plant. Pathol. 2010, 44, 909-917. [CrossRef]

49. Hadian, S.; Rahnama, K.; Jamali, S.; Eskandari, A. Comparing neem extract with chemical control on Fusarium oxysporum and Meloidogyne incognita complex of tomato. Adv. Environ. Biol. 2011, 5, 2052-2057.

50. Arif, M.; Chawla, S.; Zaidi, N.W.; Rayar, J.K.; Singh, U.S. Development of specific primers for genus Fusarium and F. solani using rDNA sub-unit and transcription elongation factor (TEF-1 $\alpha$ ) gene. Afr. J. Biotechnol. 2014, 11, 444-447. [CrossRef]

51. Uribe-Cortés, T.B.; Silva-Rojas, H.V.; Mendoza-Onofre, L.E.; Velázquez-Cruz, C.; Rebollar-Alviter, N. Identificación de especies de Fusarium aisladas de semillas sintomáticas y asintomáticas de maíz con base en el gen TEF-1 $\alpha$. Rev. Fitotec. Mex. Publ. Por La Soc. Mex. De Fitogenética 2020, 43, 79. [CrossRef]

52. Huang, S.; Xu, Y.; Yan, X.; Shang, Y.; Zhu, P.; Tian, W.; Xu, W. Development and application of a quantitative loop-mediated isothermal amplification method for detecting genetically modified maize MON863. J. Sci. Food Agric. 2015, 95, 253-259. [CrossRef]

53. Singh, R.; Singh, D.P.; Savargaonkar, D.; Singh, O.P.; Bhatt, R.M.; Valecha, N. Evaluation of SYBR green I based visual loopmediated isothermal amplification (LAMP) assays for genus and species-specific diagnosis of malaria in P. vivax and P. falciparum endemic regions. J. Vector Borne Dis. 2017, 54, 54-60.

54. Zhang, X.; Zhang, H.; Pu, J.; Qi, Y.; Yu, Q.; Xie, Y.; Peng, J. Development of a Real-Time Fluorescence Loop-Mediated Isothermal Amplification Assays for Rapid and Quantitative Detection of Fusarium oxysporum f. sp. cubense Tropical Race 4 In Soil. PLoS ONE 2013, 349, 127-134. [CrossRef] [PubMed]

55. Ayukawa, Y.; Hanyuda, S.; Fujita, N.; Komatsu, K.; Arie, T. Novel loop-mediated isothermal amplification (LAMP) assays with a universal QProbe can detect SNPs determining races in plant pathogenic fungi. Sci. Rep. 2017, 7, 4253. [CrossRef] [PubMed]

56. Ghosh, R.; Tarafdar, A.; Sharma, M. Rapid and sensitive diagnoses of dry root rot pathogen of chickpea (Rhizoctonia bataticola (Taub.) Butler) using loop-mediated isothermal amplification assays. Sci. Rep. 2017, 7, 42737. [CrossRef] [PubMed]

57. Peng, J.; Zhang, H.; Chen, F.P.; Zhang, X.; Xie, Y.X.; Hou, X.W.; Li, G.Y.; Pu, J.J. Rapid and quantitative detection of Fusarium oxysporum $\mathrm{f}$. sp. cubense race 4 in soil by real-time fluorescence loop-mediated isothermal amplification. J. Appl. Microbiol. 2015, 117, 1740-1749. [CrossRef]

58. Cao, Y.Y.; Wang, L.; Duan, L.; Li, J.; Ma, J.; Xie, S.; Shi, L.; Li, H. Development of a real-time fluorescence loop-mediated isothermal amplification assays for rapid and quantitative detection of Ustilago maydis. Sci. Rep. 2017, 7, 13394. [CrossRef] [PubMed]

59. Lu, C.; Dai, T.; Zhang, H.F.; Wang, Y.C.; Zheng, X.B. Development of a Loop-Mediated Isothermal Amplification Assays to Detect Fusarium oxysporum. J. Phytopathol. 2015, 163, 63-66. [CrossRef]

60. Lan, C.Z.; Ruan, H.C.; Yang, X.J.; Yao, J.A.; Jiang, J.X. Development of a loop-mediated isothermal amplification assays for sensitive and specific detection of Fusarium oxysporum f. sp. cucumerinum Owen. Phytoparasitica 2018, 46, 283-293. [CrossRef]

61. Olivares, B.O.; Rey, J.C.; Lobo, D.; Navas-Cortés, J.A.; Gómez, J.A.; Landa, B.B. Fusarium Wilt of Bananas: A Review of Agro-Environmental Factors in the Venezuelan Production System Affecting Its Development. Agronomy 2021, 11, 986. [CrossRef] 